\title{
In vitro Propagation of Citrus Species through Callus Induction and Regeneration: A Review
}

\author{
Mudasir Iqbal $^{1}{ }^{*}$, V. K. Wali ${ }^{1}$, Parshant Bakshi ${ }^{1}$, Kiran Kour ${ }^{1}$, \\ Vijay K. Razdan', B. K. Sinha ${ }^{2}$ and K. K. $\operatorname{Sood}^{3}$ \\ ${ }^{1}$ Division of Fruit Science, ${ }^{2}$ Division of Plant Pathology, ${ }^{3}$ Division of Agroforestry, Faculty of \\ Agriculture, Main Campus, Chatha, Sher-e-Kashmir University of Agricultural Sciences \& \\ Technology of Jammu, J\&K-180009, India
}

*Corresponding author

\begin{tabular}{|l|}
\hline Ke y w o r d s \\
Tissue culture, \\
Micropropagation, \\
Callus, \\
Regeneration, \\
Rooting, \\
Acclimatization \\
\hline Article Info \\
\hline $\begin{array}{l}\text { Accepted: } \\
17 \text { September } 2019 \\
\text { Available Online: } \\
10 \text { October } 2019\end{array}$ \\
\hline
\end{tabular}

\section{A B S T R A C T}

Citrus, one of the most important group of fruit crops around the world, are propagated at large scale with many difficulties. Propagation through seeds is challenging because of Phytophthora foot rot together with recalcitrance of citrus seeds. Vegetative propagation of Citrus species is mainly performed now-a-days by budding on seedling rootstocks. As heavy losses are experienced among the susceptible seedlings due to Phytophthora and Citrus tristeza virus (CTV), the interest in resistant rootstocks has greatly increased. The potential of conventional methods of citrus plant breeding of rootstocks are limited by physiological factors such as heterozygosity, inbreeding depression, nucellar polyembryony and juvenility. Under such conditions advanced tissue culture techniques provide best possible alternative for producing large number of resistant progenies from elite citrus genotypes. Plant tissue culture provides reliable and economical method of maintaining pathogen free plants that allows rapid multiplication and international exchange of germplasm. Generally, when in vitro propagation protocols are developed for any specific plant species, specialized conditions for individual genotypes, elite species and even various developmental stages of the explants plants are selected via error-andtrial experiments. Because large diversity is observed in Citrus plant family, it takes many months to develop protocols for most suitable culture medium, best concentrations and combinations of plant growth regulators and other supplements for better development of explant cultures. Therefore, in this review, we tried to put together results from difficultto-find literatures and listed all the identified findings, in which callus induction or somatic organogenesis was used to develop citrus plants. Successful protocols of surface sterilization method, culture establishment, shoot regeneration, in vitro rooting and acclimatization are presented systematically. 


\section{Introduction}

Citrus (Citrus sp.) is collective generic term comprising a number of species and varieties of fruits known to the world for their characteristic flavour, attractive range of colours and uses (Raja, 2012). Citrus is believed to have originated in the part of Southeast Asia bordered by Northeastern India, Myanmar (Burma) and the Yunnan province of China (Scora, 1975; Gmitter and $\mathrm{Hu}, 1990$; Liu et al., 2012). They are longlived perennial crops grown in more than 100 countries across the world (Saunt, 1990). The citrus growing belts of the world are concentrated in tropical and subtropical regions where suitable soil and climatic conditions prevail (Kaur, 2016).

Citrus is considered as the number one fruit of the world due to its high nutritional value, great production potential and preparation of large number of fruit products from them (Kour and Singh, 2012). Citrus fruits are known for their distinctly pleasant aroma, arising due to terpenes present in the rind ( $\mathrm{Li}$ et al., 2014). The genus derives its commercial importance from its fruits, which are of great economic and health value and are consumed fresh or pressed to obtain juice (Talon and Gmitter Jr., 2008). Citrus peels too have no less importance and can be candied, used as livestock feed, in perfumeries, bakeries and in soap industry (Dhanavade et al., 2011). Lemon oil obtained by cold pressing of lemon peels is extensively used in furniture polish (Bansode et al., 2012). Citrus has been utilized in a number of medicinal preparations for the remedy of scores of ailments ranging from toothache, diarrhea, constipation, and insomnia to vomiting (Singh and Rajam, 2010). It carries bioactive secondary components which are working against cancer and degenerative diseases (Karimi et al., 2012). The medicinal practitioners commonly suggest consuming citrus fruits for obtaining minerals, vitamins and other necessary components so as to recover weak health by improving appetite quickly (Rakesh et al., 2013). The flavonoids of citrus play an important role in preventing progression of hyperglycemia by increasing the glycogen, hepatic glycolysis and reducing the hepatic gluconeogenesis (Shen et al., 2012).

The primary reason for shifting citriculture from seedling to budded plants was the appearance of Phytophthora "foot rot" in Azores Islands in 1842 (Singh and Naqvi, 2001). Since early 1950s extensive rootstock trials on citrus have been conducted under different environmental conditions (Bhattacharya and Dutta, 1952; Rangacharlu et al., 1958 and Singh, 1962). Further, the citrus root stock scenario in India has been reviewed by (Agarwal, 1982); (Randhawa and Srivastava, 1986); (Patil, 1987) and (Chadha and Singh, 1990). The dominant sour orange rootstock has been replaced by rough lemon rootstock which was tolerant to CTV (Chamandoosti, 2017).

Rough lemon is highly vulnerable to Phytophthora, which leads to main losses in an orchard if appropriate phyto-sanitary conditions are not followed (Mukhtar et al., 2005a, Savita et. al. 2010, Sarma et al., 2011 and Kasprzyk-Pawelec et al., 2015). The potential of conventional methods of upgrading of citrus rootstocks is limited by biological factors that hinder breeding and selection, such as heterozygosity and inbreeding pollen and ovule sterility, sexual incompatibility, apomixes, depression, nucellar polyembryony and juvenility (Guo and Deng, 2001; Guo and Grosser, 2005) (Tusa et al., 1990, Carimi et al., 1994, Savita et al., 2010, Benabdesselam et al., 2011, Lombardo et al., 2011). In vitro culture is a method that can resolve this problem and can also produce crops on a comparatively large scale in comparison with conventional plant 
breeding (Kasprzyk-Pawelec et al., 2015). Under such circumstances, in vitro culture techniques hold potential and could present solution to these problems

Tissue culture and micropropagation practice have been developed from different explants sources for number of Citrus spp., Therefore, the aim of this review is to focus on the use of the former pathway, most probably the technique previously employed for micropropagation of citrus, and an attempt has been made to present a comprehensive available literature related to tissue culture in Citrus species under the following headings and sub-headings.

\section{Tissue culture studies in citrus species}

Studies on citrus tissue culture in vitro were set off in early Nineteen Fifties with the aim of genetic improvement of the species as well as to get virus free plants. It has been suggested that plant tissue culture would play a very significant role in conservation and genetic improvement for large scale propagation of plants in India (Raja, 2012).

Plant tissue culture has come into view as a powerful tool for propagation and improvement of many woody plant species including Citrus. The genetic and epigenetic mechanism of callus formation, the widespread use and knowledge of molecular mechanisms and the underlying induction of callus, deserve to be studied systematically (Momoko et al., 2013). In vitro culture has the potential to eradicate diseases and provides scope for development of new cultivars through somaclonal variations (Hammschlag et al., 1995). Despite its rich genetic resources, scientists come across difficulties in citrus hybridization breeding due to high sterility, heterozygosity, incompatibility and nucellar embryos (Shen et al., 1998). With the development of biotechnology, genetic transformation and protoplast hybridization have been recognized to avoid those breeding obstacles in many fruit trees (Deng and Liu, 1996). For citrus, embryogenic callus is extensively used in genetic transformation and protoplast hybridization since it can simply regenerate plants (Deng and Liu, 1996; Hao, 2000; Hao and Deng, 2002). Citrus embryogenic calluses can be maintained in culture at one month intervals for a long period (Hao and Deng, 2002; Yi and Deng, 1998). However, recurrent subculture of numerous cultures is labour intensive and costly (Engelmann, 1997; Ashmore, 1997). To resolve this problem, short and medium term storage methods have been developed to lessen growth and increase subculture intervals. Tissue culture protocols have been described for a number of Citrus spp. through callus (Singh and Rajam, 2009; Savita et al., 2010, 2011a, 2011b; Ali and Mirza, 2006; Altaf et al., 2008; Altaf et al., 2009a,b; Khan et al., 2009; Laskar et al., 2009; Kaur, 2018 and Taye et al., 2018).

\section{Sterilization procedures of explants}

Sterilization is a very important and basic aspect of tissue culture, as it actually aims at in vitro propagation of progenies of desired genotypes free from surface and systemic contamination. The explants collected from field grown seedlings harbour many microbial pathogens like fungi and bacteria, in addition to adhered soil particles thus, it necessities a thorough and effective surface sterilization of explants before culturing. Mercuric chloride seems as the best sterilizing gent as preferred by Ali and Mirza 2006, Savita et al., 2011b, Saini et al., 2010 and Kour, 2016 in Citrus jambhiri at the concentration of $0.1 \%$ treated for 4-5 minutes, Kanwar et al., 2016 in Sour orange at the concentration of $0.1 \%$ treated for 1 minute, in addition sodium hypochlorite $(\mathrm{NaOCl})$ is also used by some others (Upadhyay et al., 2010 in Sweet orange cv. 
Mosambi). In addition Taye et al., 2018 used fungicides like Kocide, Bayleton and Redimol each with the concentration of $0.25 \mathrm{~g} / 100 \mathrm{ml}$ of water for 15 and 20 minutes. The surface sterilization of explants with $70 \%$ aqueous solution of ethanol for 30 seconds followed by $0.1 \%$ mercuric chloride for 8-10 minutes and then thoroughly washing with sterile distilled water in citrus was reported by (Sharma et al., 2009). Pre-sterilization of excised explants with Benomyl $(0.2 \%)$ can improve a cleanness and aliveness of all types of explants, especially when followed through surface sterilization done by mercury chloride $\left(\mathrm{HgCl}_{2}\right)$ (Nurul, et al., 2012). Kour and Singh 2012 removed expanded leaves of Rough lemon as explants and then treated them with $10 \%$ solution of teepol detergent for 10 minutes followed by thorough washing with distilled water. They further preferred treatment of explants with $70 \%$ ethanol for 30 seconds followed by $0.1 \%$ mercuric chloride treatment for 8 minutes and then rinsing with autoclaved distilled water three times.

\section{Culture establishment}

Callus formation is controlled by the level of plant growth regulators (auxin and cytokinins) in the culture media. Concentrations of plant growth regulators can vary for each plant species and can even depend on the sources of explants or individual plant. Culture conditions (temperature, light) are also important. Protocols developed in previous studies have shown that plant growth regulator concentration and selection are vital for citrus callus induction.

\section{Explant type, media composition and callus induction}

The major advantages of using seedlings explants over explants taken from field-grown mature plants are their high multiplication rates and high regeneration potentials
However, the disadvantages are very known, including insufficient knowledge regarding their genetic background. Das et al., (2000) in their study developed a protocol for micropropagation of elite plants of sweet orange (Citrus sinensis) through nucellar embryo culture and found that MS medium supplemented with NAA $(1.0 \mathrm{mg} / \mathrm{l})$ or $2,4-\mathrm{D}$ $(1.0 \mathrm{mg} / \mathrm{l})$ encouraged callus development in both nucellar and zygotic embryos. Al-Khayri and Al-Bhrany (2001) in their study on micropropagation in lime Citrus aurantifolia using nodal explants of mature tree nodes found best multiple shoot formation, i.e. 8.0 shoots per node on MS medium supplemented with $1.0 \mathrm{mg} / \mathrm{l}$ BAP and $0.5 \mathrm{mg} / \mathrm{l}$ kinetin. Srivastava et al., (2001) in their study on vitro plant regeneration of Citrus aurantifolia through callus culture, shoot tip, epicotyls and hypocotyl segments reported callusing on MS medium enriched with BAP $(5.0 \mathrm{mg} / \mathrm{l})$ and observed highest per cent of callus and shoot regeneration with $5.0 \mathrm{mg} / \mathrm{l} \mathrm{BAP}$. Kamble et al., (2002) in their study on in vitro micropropagation and callus induction in acid lime (Citrus aurantifolia) cv. Sai Sarbati observed the highest callus induction with epicotyl cultured on half-strength of MS medium supplemented with NAA (10.0 mg/l) and BAP (0.5 mg/l). Karwa Alka (2003) carried research on in vitro propagation of Citrus reticulata (Nagpur mandarin) through mature seeds and found the highest (80\%) of shoot induction and multiple shoots per explants when cultured on MS medium supplemented with BA $(8.80 \mu \mathrm{M})$, NAA (2.69 $\mu \mathrm{M})$ and kinetin $(2.32 \mu \mathrm{M})$. Singh et al., (2004) obtained multiple shoots on shoot tips (2.0 to $3.0 \mathrm{~mm}$ ) derived from mature plants $(5$ to 6-year-old) of Citrus reticulata Blanco cv. Khasi mandarin and $C$. limon Burm.f. cv. Assam lemon, when cultured on Murashige and Skoog (MS) medium, supplemented with $1.0 \mathrm{mg} / \mathrm{l} \mathrm{BAP,} 0.5 \mathrm{mg} / \mathrm{l}$ kinetin, and $0.5 \mathrm{mg} / \mathrm{l}$ NAA. Mukhtar et al., (2005) reported that callus induction was greatest when shoot 
segments of lime were cultured on MS medium containing 2, 4-D and coconut milk. Further, embryo proliferation was greatest on MS medium supplemented with kinetin (1.5 $\mathrm{mg} / \mathrm{l})$. In addition, shoot induction was highest on MS medium along with BAP $(2.0 \mathrm{mg} / \mathrm{l})$. Ali and Mirza (2006) observed optimal callus induction response on MS medium, supplemented with 2,4-D $1.5 \mathrm{mg} / \mathrm{l}$ from all types of explants, with highest response (92\%) and maximum shoot regeneration response (70 $\%$ ) from callus on MS medium supplemented with BA 3 mg/l. Saini et al., (2010 observed maximum bud induction frequency of $83.97 \%$ on MS medium supplemented with BA $(0.5$ $\mathrm{mg} / \mathrm{l})$ with an average of 8.6 buds per explant. Kumar et al., (2011) obtained maximum callusing in epicotyl segments on MS medium supplemented with NAA $(10.0 \mathrm{mg} / \mathrm{l})$ in combination with BA (1.0 mg/l), KN (0.5 $\mathrm{mg} / \mathrm{l})$, sucrose $(6 \%)$ and galactose $(3 \%)$. Savita et al., (2010) reported that the maximum callus induction (98.66\%) were found from leaf segments on MS medium supplemented with 2, 4-D (4.0 mg/l). Further in nodal segments, maximum callus induction $(96.00 \%)$ was observed with 2, 4-D (1.0 mg/l) and in root segments; it was $48.66 \%$ on MS medium supplemented with 2, 4-D (2.0 mg/l).

Savita et al., (2011b) found maximum callus induction of $91.66 \%$ on MS medium supplemented with 2, 4-D $(2.0 \mathrm{mg} / \mathrm{l})$ in combination with $\mathrm{ME}(500 \mathrm{mg} / \mathrm{l})$. Further, maximum shoot regeneration of $87.50 \%$ was observed with BA $(3.0 \mathrm{mg} / \mathrm{l})$. In vitro multiplication of $C$. jambhiri through the nodal explant on MS medium supplemented with BAP $(1.5 \mathrm{mg} / \mathrm{l})$ and malt extract (500 $\mathrm{mg} / \mathrm{l})$ established highest number of shoots per explant in minimum time (Kour and Singh 2012). Kasprzyk-Pawelec et al., (2015) observed best shoot induction when the leaf explants were cultured on Murashige and Tucker media (MT) supplemented with BAP (3.5 mg/l). MS medium supplemented with 2 ,
4-D $(1.0 \mathrm{mg} / \mathrm{l})$ in combination with BAP (1.0 $\mathrm{mg} / \mathrm{l})$ produced early and highest percentage of callus with formation of somatic embryos (Kaur, 2018). Taye et al., (2018), in their study on optimization of an in vitro regeneration protocol for Rough lemon rootstock (Citrus jambhiri Lush.) via direct organogenesis reported that almost all IBA and BA treatments resulted in almost cent percent shoot induction except IBA $(0.1 \mathrm{mg} / \mathrm{l})$, BA (1.5 and $2.0 \mathrm{mg} / \mathrm{l})$. Further, it was reported that among the explant sources, nodal segments induced a higher percentage of longer shoots in a shorter period of time than shoot tips.

\section{Shoot regeneration and multiplication}

The inherent capacity of plant cells to give rise to complete plant is described as 'Cellular totipotency'. For a differentiated cell to express its totiotency it first reverts to meristimatic stage and forms undifferentiated callus tissue (dedifferentiation) followed by forming whole plant or plant organ (redifferentiation). Al-Khayri and Al-Bahrany (2001) reported that multiple shoots from nodal segment of lime (Citrus aurantifolia (Christm.) on MS medium supplemented with BAP, kinetin and NAA. Ali and Mirza (2006) reported maximum shoot regeneration response $(70 \%)$ from callus on MS medium supplemented with BA (3.0 mg/l). PerezTornero and Tallo'nI.Porra (2008) tried several combinations of BAP and Gibberellic acid $\left(\mathrm{GA}_{3}\right)$ to optimize the proliferation phase and found that the numbers of shoots were dependent on the BA and GA concentrations and the best results were observed with 2.0 $\mathrm{mg} / \mathrm{l} \mathrm{BAP}$ and 1.0 or $2.0 \mathrm{mg} / \mathrm{l} \mathrm{GA}$. Sharma et al., (2009) obtained maximum number of shoots per plant through the callus in Pectinifera, rough lemon and Cleopatra mandarin on MS basal medium with $1.0 \mathrm{mg} / \mathrm{l}$ BAP. Saini et al., (2010) reported higher number of elongated shoots on MS medium 
having BA $0.5 \mathrm{mg} / \mathrm{l}$ and GA3 $1.0 \mathrm{mg} / \mathrm{l}$, while studying direct shoot organogenesis and plant regeneration in rough lemon. Upadhyay et al., (2010) found MS medium supplemented with BAP $(2.0 \mathrm{mg} / \mathrm{l})$ in combination with $\mathrm{KN}(1.0$ $\mathrm{mg} / \mathrm{l})$ and NAA $(0.1 \mathrm{mg} / \mathrm{l})$ as the best treatment multiplication medium with maximum shoot length and highest number of leaves. Kumar et al., (2011) concluded that the maximum shoot regeneration of $76.09 \%$ was achieved on MS medium supplemented with NAA $(0.5 \mathrm{mg} / \mathrm{l})$ in combination with BA $(3.0$ $\mathrm{mg} / \mathrm{l})$ and $\mathrm{KN}(0.5 \mathrm{mg} / \mathrm{l})$ and highest regeneration potential on medium supplemented with sucrose $(6.0 \%)$ and maltose $(2.0 \%)$ and it decreased ever more with increase in the age of callus from 40 to 120 days. Savita et al., (2010) established a protocol for micropropagation of $C$. jambhiri via callus induction and regeneration and reported that callus raised from leaf segments showed maximum regeneration of $57 \%$ on MS medium supplemented with NAA (0.5 $\mathrm{mg} / \mathrm{l})$ and BA (1.0 $\mathrm{mg} / \mathrm{l})$, where as nodal segments showed better regeneration of 71.89 $\%$ on MS medium augmented with NAA (0.5 $\mathrm{mg} / \mathrm{l})$ and BA (3.0 mg/l. Savita et al., (2011b) further developed an efficient micropropagation protocol for Citrus jambhiri Lush. using cotyledons as explants and reported maximum shoot regeneration (87.50 $\%)$ on MS medium supplemented with BA $(3.0 \mathrm{mg} / \mathrm{l})$. It was also reported that the callus retained regeneration capacity $(58.33 \%)$ even after 420 days of culture. Kasprzyk-Pawelec et al., (2015) in in vitro organogenesis using Citrus limon L. Burm cv. 'Primofiore' leaf explants reported the best shoot induction when the leaf explants were cultured on Murashige and Tucker media supplemented with $3.5 \mathrm{mg} / \mathrm{l} \mathrm{BAP.} \mathrm{Sarker} \mathrm{et} \mathrm{al.,} \mathrm{(2015)} \mathrm{found}$ that semi solid MS medium having BAP (1.5 $\mathrm{mg} / \mathrm{l})$ in combination with $\mathrm{GA}_{3}(0.5 \mathrm{mg} / \mathrm{l})$ established as best medium formulation for proper shoot regeneration and elongation. Kanwar et al., (2016) conducted a study on micro propagation technique for Sour Orange (Citrus aurantium L.) using nodal explants of mature trees, and reported that best shoot formation of 7.4 shoots per node on MS medium containing BAP $(1.0 \mathrm{mg} / \mathrm{l})$ combined with Kinetin (0.5 mg/l). Kaur (2016) during in vitro plant regeneration in Rough lemon (Citrus jambhiri Lush.) through epicotyl segments by direct shoot organogenesis obtained maximum number of elongated shoots (8.50) on MS medium having BAP (0.5 $\mathrm{mg} / \mathrm{l})$ combined with Gibberellic Acid $\left(\mathrm{GA}_{3}\right)$ (1.0 mg/l). Taye et al., (2018) observed longer shoots with $0.1 \mathrm{mg} / 1 \mathrm{GA}_{3}$ than culture medium without this plant growth regulator. Kaur (2018) developed an efficient protocol for in vitro embryogenic callus induction and regeneration of Rough lemon (Citrus jambhiri Lush.). It was reported that MS medium fortified with NAA $(0.5 \mathrm{mg} / \mathrm{l})$ combined with BAP $(3.0 \mathrm{mg} / \mathrm{l})$ and kinetin $(1.0 \mathrm{mg} / \mathrm{l})$ had good regeneration potential, highest number of shoots and shoot length and took minimum number of days for regeneration.

\section{In vitro rooting}

In vitro good quality of root induction is a known phenomenon due to plant growth regulators (auxins). The plant growth regulators (IAA, IBA and NAA) have been popularly considered as rooting hormones in plant tissue culture. Paudyal and Haq (2000) found that NAA was superior to IBA for in vitro root induction $(75 \%)$ in Pummelo when shoots were transferred into half strength MS medium supplemented with 1.3, 2.7 and 5.4 $\mu \mathrm{M}$ of NAA. Krishan et al., (2001) has found good response for in vitro rooting in Mosambi (Jaffa). Further recorded longest regenerated roots of $5.33 \mathrm{~cm}$ on half strength MS medium supplemented with NAA $(0.5 \mathrm{mg} / \mathrm{l})$ combined with IBA $(0.5 \mathrm{mg} / \mathrm{l})$. Singh et al., (2001) observed paclobutrazol showing significant effect on rooting in citrus. Further, they recorded that root length reduction was more 
pronounced in Assam lemon than Sweet lime, may be due to reduced the biosynthesis of gibberellins as a result of paclobutrazol addition. Al-Khayri and Al-Bhrany (2001) observed the highest rooting on medium containing either NAA $(1.5 \mathrm{mg} / \mathrm{l})$ alone or NAA (0.5 mgl/1) combined with (IBA 2.0 $\mathrm{mg} / \mathrm{l})$. Further they observed that the highest number of roots were produced on a treatment containing both NAA $(2.0 \mathrm{mg} / \mathrm{l})$ and IBA $(2.0$ $\mathrm{mg} / \mathrm{l})$ whereas, most of the elongated roots were found in the treatment containing 0.5 $\mathrm{mg} / \mathrm{l}$ of either NAA or IBA. Kaya and Gubbuk (2001) conducted a study on in vitro propagation and rooting in some citrus rootstock through tissue culture in Troyer citrange and Carrizo on MS medium supplemented with BAP (1.0 mg/l), NAA (1.0 $\mathrm{mg} / \mathrm{l})$ and $\mathrm{GA}_{3}(1.0 \mathrm{mg} / \mathrm{l})$. They observed that they had optimum growth and development other than MS supplemented with BA (1.0 $\mathrm{mg} / \mathrm{l})$ and NAA $(1.0 \mathrm{mg} / \mathrm{l})$ in Sour orange cv. Trunk. Wang et al., (2002) achieved $87 \%$ rooting frequency, when in vitro raised shoots were cultured into MT medium supplemented with NAA at $0.5 \mathrm{mg} / \mathrm{l}$ in Citrus reticulata var. tankan hayata. Singh et al., (2003) has studied the effect of bio-regulators on rooting of in vitro raised micro shoots in two Citrus species, namely, Khasi mandarin and Sweet lime and recorded that medium having NAA at $0.1 \mathrm{mg} / \mathrm{l}$ resulted in the maximum rooting $(87.71 \%)$ and longer root length of $46.79 \mathrm{~mm}$. Paclobutrazol increased root diameter but reduced root length. The growth regulators in Sweet lime registered a lower rooting percentage $(6.83 \%)$ than mandarin $(51.75 \%)$. Karwa and Chikhale (2004) studied that the effect of various growth hormones on in vitro clonal propagation of Citrus sinensis and found that IBA $(2.64 \mu \mathrm{M} / 1)$ as best treatment with $100 \%$ of the explants producing roots among different concentration of IBA (0.98 to $4.9 \mu \mathrm{M} / 1$ ). Silva et al., (2005) found that rooting in Citrus reshni mandarin was best achieved, when in vitro raised shoot on MS medium half-strength was supplemented with NAA $(1.0 \mathrm{mg} / \mathrm{l})$. Also concluded that half strength of MT medium without auxin resulted in the maximum rooting of regenerated shoots. Ali and Mirza (2006) reported that MS medium supplemented with NAA $(0.5 \mathrm{mg} / \mathrm{l})$ provided $70 \%$ of rooting response in Citrus jambhiri. EI-Sawy et al., (2006) found that rooting in citrus was best using micro shoots regenerated from nodal explants. Treatments including MS medium with IBA at $0.0,0.5$ and $1.0 \mathrm{mg} / \mathrm{l}$ and NAA at $0.0,0.5$ and $1.0 \mathrm{mg} / \mathrm{l}$ were evaluated for rooting and NAA at 0.5 $\mathrm{mg} / \mathrm{l}$ resulted in best rooting response among all the treatments. Pe'rez-Tornero et al., (2008) obtained highest rooting percentages on media containing IBA $(3.0 \mathrm{mg} / \mathrm{l})$ alone or in combination with) IAA $(1.0 \mathrm{mg} / \mathrm{l}$. The average root length was affected significantly by the IBA and IAA concentrations. Root length was greater when only $3.0 \mathrm{mg} / \mathrm{l} \mathrm{IBA}$ was used, also explants had a better appearance, with greener and larger leaves. While studying in vitro propagation of citrus rootstocks viz. Rough lemon, Cleopatra mandarin Pectinifera and Troyer citrange Sharma et al., 2009 reported maximum rooting of shoots $(1.11 \%)$ in rootstock Rough lemon followed by Cleopatra mandarin for the MS media (half strength) supplemented with IBA (10 mg/l). Saini et al., (2010) reported highest rooting percentage of $77 \%$ on MS medium containing NAA $(1.0 \mathrm{mg} / \mathrm{l})$ combined with IBA $(1.0 \mathrm{mg} / \mathrm{l})$ in Citrus jambhiri. Savita et al., (2010) found best rooting response (71 $\%)$ with NAA $(0.5 \mathrm{mg} / \mathrm{l})$ and reported that callus from root segments did not regenerate in Citrus jambhiri. While studying, an efficient plant regeneration protocol from callus cultures of Citrus jambhiri Lush. (Savita et al., 2011) reported maximum rooting response $(91.67 \%)$ on half strength MS medium supplemented with NAA (0.5 mg/l). Kasprzyk-Pawelec et al., (2015) reported best rooting response of $82 \%$ using the MS medium with NAA (1.0 mg/l). Kaur 
(2016) obtained highest rooting percentage of $96 \%$ and root number on MS medium containing IBA $(0.1 \mathrm{mg} / \mathrm{l})$ combined with IAA (0.5 mg/l). Sarker et al., (2015) found best root induction (100\%) on MS medium having NAA $(0.5 \mathrm{mg} / \mathrm{l})$ in Citrus aurantifolia. Kaur (2018) observed that rooting of regenerated shoots was highest in MS supplemented with NAA $(1.0 \mathrm{mg} / \mathrm{l})$ and IBA $(1.0 \mathrm{mg} / \mathrm{l})$ and took minimum number to rooting in Citrus jambhiri. Taye et al., (2018) reported longest roots with MS medium (half strength) supplemented with $\mathrm{GA}_{3}(0.1 \mathrm{mg} / \mathrm{l})$.

\section{Hardening and planting out}

In vitro propagation technique has been widely used for development of disease free plants, their improvement and rapid multiplication in many crop plants. However, its wider use often gets restricted by high percentage of plant loss or death whenever transferred to natural environmental conditions. The acclimatization and survival of in vitro hardened plantlets in natural field conditions is the ultimate and important step. Eden and Cerruti (2008) successfully acclimatized 7-8 cm heighted and well rooted shoots in partial shading that can initially reduce light by 50 percent. Anita et al., (2000) found that bacterial inoculum enhanced the survival rate of in vitro hardened plantlets and there was increase (30-50\%) in survival rate. Pospisilova et al., (1999) indicated different abnormalities from in vitro acclimatized plants due to the suddenly changed environmental conditions. Hazarika and Parthasarathy (2002) have also reported the beneficial effects of reduced humidity and antitranspirants use for successful in vitro hardening and ex vitro survival of citrus plantlets. Darwesh and Rasmia (2015) studied the in vitro isolated plantlets transferred to acclimatize in greenhouse in peat of moss and perlite $(2: 1)$ kept in plastic cover with inside $100 \%$ humidity and noted their better normal growth. During the present work, the fine sand and coco peat mixture placed in the shade with low light intensity, succeeded in showing normal growth and functioning of the plants. Kumar and Rao (2012), by using lower relative humidity, higher light intensity and septic environmental condition, reported good amount of success as regards hardening. Normah et al., (1997) reported $83.33 \%$ survival of regenerated plantlets of Citrus halimii under ex-vitro conditions. Al-Khayari and Al-Baharany (2001) reported $90 \%$ survival of regenerated plantlets of Citrus aurantifolia. Rani et al., (2004) reported 67\% survival rate of rooted plantlets of Kinnow. Altaf et al., (2008) reported $76 \%$ survival of regenerated plantlets of Citrus jambhiri. Citrus is vast genera comprising of many economically important species and varieties across the world. Citrus species are infected by several microorganisms like bacteria, fungi, viruses and mycoplasma causing severe economic losses. Microorganism infestation is easily transferred through seed as well as vegetative means of propagation. The demand and need of citrus industry is to develop high yielding progenies as well as to get biotic and abiotic stress resistant root stock as a planting material. Therefore, like majority of vast genera and plant species, Citrus also needs improvement to develop resistant genotypes. The conventional citrus breeding methods are limited due to difficulties such as heterozygosity, inbreeding depression, nucellar polyembryony and juvenility. Under such conditions in vitro standardized protocol of citrus micropropagation would prove useful for rapid multiplication of plants. It can be concluded that the citrus species can be successfully be micropropagated employing seedling explants like leaf, epicotyl and nodal segments though callus induction with good multiplication rates and regeneration potential on different media composition with different combinations and concentrations of plant growth regulators cited within the manuscript (Fig. 1). 
Fig.1 Typical events during propagation of Citrus spp. through callus induction as exemplified by Citrus jambhiri. A. Inoculation of leaf explants B. Callus induction from leaf segments $\mathbf{C}$. Callus regeneration D. Shoot regeneration after subculturing E. Rooting of regenerated shoots F. Planting out after acclimatization

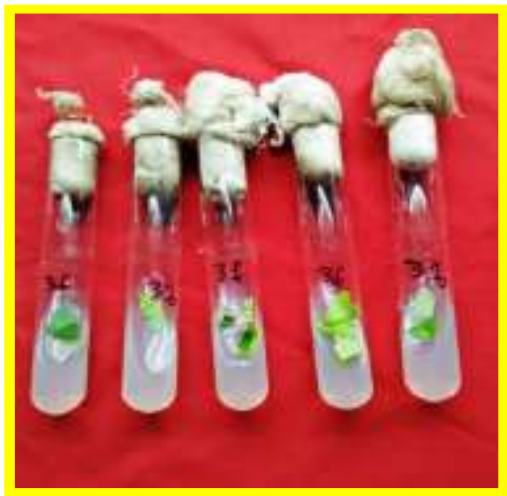

A

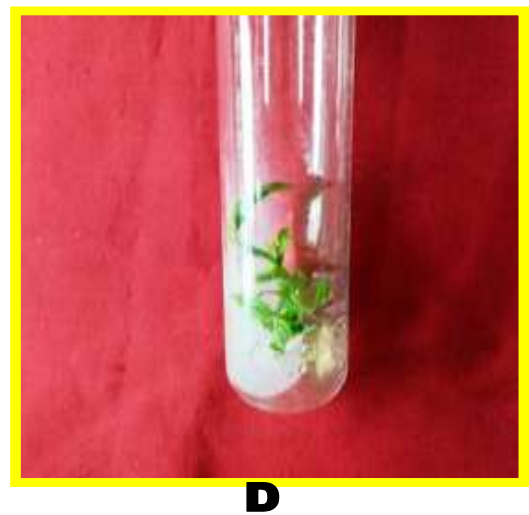

References

Agarwal, P. K. 1982. Performance of different citrus root stocks in India: A Review. Agricultural Review, 3: 17-34.

Ali, S. and Mirza, B. 2006. Micropropagation of Rough lemon (Citrus jambhiri Lush.). Effect of explant type and hormone concentration. Acta Botanica Croatica, 65: 137-146.

Al-Khayri, J. M. and Al-Bahrany, A. M. 2001. In vitro micropropagation of Citrus aurantifolia (lime). Current Science, 81: 1242-1246.

Altaf, N., Khan, A. R., Ali, L. and Bhatti, I. A. (2009b). In vitro culture of Kinnow explants. Pakistan Journal of Botany, 41: 597-602.

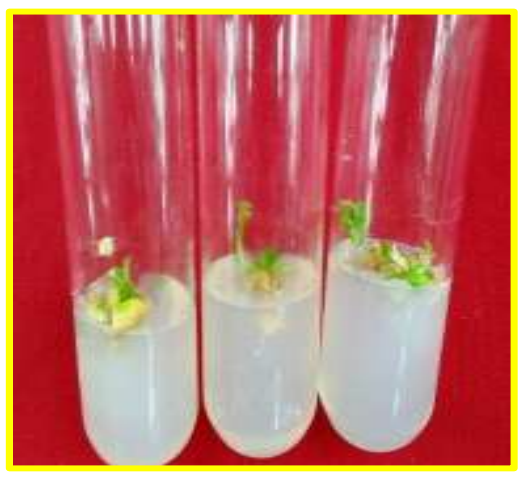

C

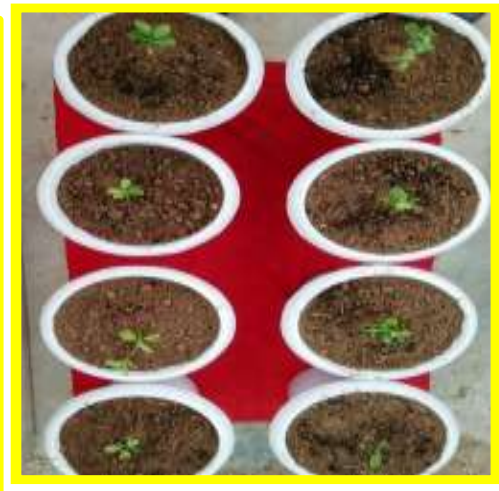

$\mathbf{F}$

Altaf, N., Khan, A. R., Ali, L. and Bhatti, I. A. 2008. Propagation of Rough lemon (Citrus jambhiri Lush.) through in vitro culture and adventitious rooting in cuttings. Electronic Journal of Environmental, Agricultural and Food Chemistry, 7: 3326-3333.

Altaf, N., Khan, A. R., Bhatti, I. A. and Ali, L. (2009a). Tissue culture of citrus cultivars. Electronic Journal of Environmental, Agricultural and Food Chemistry, 8: 43-51.

Anita, P., Lokman, P. and Niladri, B. 2000. Biological hardening of tissue culture raised tea plants through rhizosphere bacteria. Kluwer Academic Publishers Biotech Let, 22: 1087-1091.

Ashmore, S. E. 1997. Status report on the 
development and application of in vitro techniques for the conservation and use of plant genetic resources, $\mathrm{pp}$. 23-24. International Plant Genetic Resources Institute, Rome.

Bansode, D. S., Chavan, M. D. 2012. Studies on antimicrobial activity and phytochemical analysis of Citrus fruit juices against selected enteric pathogens. Internat. Res. J. Pharm., 3(11): 122-126.

Benabdesselam, F., Khettal, B. and Bedjou, F. 2011. Micropropagation of Algerian juvenil rootstocks citrus species. Life sciences Leaflets, 18:707 -717.

Bhattacharya, S. C. and Dutta, S. 1952. A preliminary observation on rootstocks for Citrus in Assam. Indian Journal of Horticulture, 9: 1-11.

Carimi, F., De Pasquale, F. and Crescimanno, F. G. 1994. Somatic embryogenesis from styles of lemon (C. limon). Plant Cell, Tissue and Organ Culture, 37:209-211.

Chadha, K. L. and Singh, H. P. 1990. Citriculture scenario of India. In:Gill, K. S., Kanwar, J. S. and Singh, R. (eds.) Proceedings Citrus Show-cumSeminar, Prospects and Problems of Kinnow Cultivation. pp 21-64, Punjab Agricultural University, Ludhiana, India.

Chamandoosti, F. 2017. The utilities of Citrus tissue culture. International Journal of Environmental and Agriculture Research, 3(9): 36-46.

Darwesh and Rasmia, S. 2015. Morphology, physiology and anatomy in vitro affected acclimatization, ex vitro date palm plantlets: A review. International Journal of Chemistry and Environmental Biological Science. 3 (2): 183-190.

Das, A., Paul, A. K. and Chaudhary, S. 2000. Micropropagation of sweet orange (Citrus sinensis Osbeck) for the development of nucellar seedlings. Indian Journal of Experimental Biology, 38: 269-272.

Deng, X. and Liu, J. H. 1996. Advances in genetic transformation and genome transfer of fruit crops. Journal of Wuhan Botanical Research, 14: 357369.

Dhanavade, M. J., Jalkute, C. B., Ghosh, J. S., Sonawane, K. D. 2011. Study antimicrobial activity of lemon (Citrus lemon L.) peel extract. Brit. J. Pharm. Toxic., 2 (3): 119-122.

Eden, A. P. and Cerruti, R. H. 2008. Preparing tissue cultured banana plantlets for field planting. Co. ext. series Agriculture Research Biotechnology, 8: 1-3.

El-Sawy, A., Gomaa, A., Reda, A. and Danial, N. 2006. Somatic embryogenesis and plant regeneration from undeveloped ovules of citrus. Arabian Journal of Biotechnology, 9: 189-202.

Engelmann, F. (1997). In vitro conservation methods. In: Callow, J. A., FordLloyd, B. V. and Newbury, H. J. (eds). Biotechnology and plant Genetic Resources. CABI, Oxon, pp. 119-161.

Gmitter, F. G. Jr. and Hu, X. 1990. The possible role of Yunnan, China, in the origin of contemporary Citrus species (Rutaceae). Economic Botany, 44: 267-277.

Guo, W. W. and Deng, X. X. 2001. Wide somatic hybrids of Citrus with its related genera and their potential in genetic improvement. Euphytica, 118: 175-183.

Guo, W. W. and Grosser, J. W. 2005. Somatic hybrid vigor in Citrus: Direct evidence from protoplast fusion of an embryogenic callus line with a transgenic mesophyll parent expressing the GFP gene. Plant Science, 168: 1541-1545.

Hammschlag, F., Ritchie, D., Werner, D., 
Hashmil, G., Krusberg, L., Meyer, R. and Huettel, R. 1995. In vitro selection of disease resistance in fruit trees. Acta Horticulturae, 392: 19-26.

Hao, Y- J. 2000. In vitro conservation and genetic variation of important fruit trees. Ph.D. thesis, Huazhong Agricultural University, Wuhan, P. R. China.

Hao, Y-J. and Deng, X. X. 2002. Occurrence of chromosomal variations and plant regeneration from long-term-cultured citrus callus. In Vitro Cellular Developmental Biology-Plant, 38: 472476.

Hazarika B. N. and Parthasarathy V. A. 2002. Effect of reduced humidity and antitranspirants in acclimatizing micropropagated citrus plantlets. Journal of Applied Horticulture, 4 (1): 30-32.

Kamble, M., Kalim, S., Bajpai, A., Chandra, R. and Kumar, R. 2012. In vitro selection for wilt resistance in guava (Psidium guajava L.) cv. Allahabad Safeda. Biotechnology, 11(3): 163-171.

Kanwar, J., Kaul, M. K., Shaktawat, R. P. S. and Naruka, I. S. 2016. In vitro multiple shoots induction from nodal explants of Sour orange (citrus aurantium 1.). The Bioscan, 11(4): 2127-2131.

Karimi, E., Oskoueian, E., Hendra, R., Oskoueian, A. and Jaafar, H. Z. 2012. Phenolic compounds characterization and biological activities of Citrus aurantium Bloom. Journal of molecular biology, 17 (2): 1203-1218.

Karwa, A. 2003. In vitro propagation of $C$. reticulata Blanco. (Nagpur mandarin). Indian J. Gen. Plant Breed. 63: 18788.

Karwa, A. S. and Chikhale, N. J. 2004. Effect of various growth hormones on Invitro clonal propagation of Citrus sinensis Osbeck. Recent Trends in
Biotechnology. Scientific Publishers (India), Jodhpur, India, pp. 192-195.

Kasprzyk-Pawelec, A., Pietrusiewicz, J., Szczuka, E. 2015. In vitro regeneration induced in leaf explants of Citrus limon L. Burm cv. 'Primofiore'. Acta Sci. Pol. Hortorum Cultus, 14(4): 143153.

Kaur, S. 2016. In vitro plant regeneration in rough lemon (Citrus jambhiri Lush.) through epicotyl segments by direct shoot organogenesis. Journal of Applied and Natural Science, 8 (2): $724-729$.

Kaur, S. 2018. In vitro somatic embryogenesis and regeneration from epicotyl segments of rough lemon (Citrus jambhiri Lush.). International Journal of Chemical Studies, 6(1): 2082-2091.

Kaya, B. and Gubbuk, H. 2001. Investigation on the propagation of some citrus rootstocks by tissue culture. Ziraat Facultesi Dergisi, Akedeniz University, 14(2): 69- 76.

Khan, E. U., Xing-Zheng, F., Wang, J., QiJun, F., Xiao-San, H., Ge-Ning, Z., Shi, J. and Ji-Hong, L. 2009. Regeneration and characterization of plants derived from leaf in vitro culture of two sweet orange (Citrus sinensis (L.) Osbeck) cultivars. Scientia Horticulturae, 120: 70-76.

Kour, K. and Singh, B. 2012. In vitro multiplication of rough lemon (Citrus jambhiri Lush.). Journal of Agriculture and Veterinary Science, 1(4): 05-09.

Krishan, K., Dhatt, A. S. and Gill, M. I. S. 2001. In-vitro plant propagation in sweet orange (Citrus sinensis L. Osbeck.) cv. Mosambi and Jaffa. Indian J. Hort., 58: 208-211.

Kumar, K. and Rao, I. 2012. Morphophysiologicals problem in acclimatization of micropropagated plants in-ex vitro conditions-A review. Journal of ornamental and 
Horticulture Plants, 2 (4): 271-283.

Kumar, K., Kaur, H., Gill, M. I. S., Rattanpal, H. S., Kanika and Gosal, S. S. 2011. An efficient regeneration protocol from callus culture in rough lemon (Citrus jambhiri). Indian Journal of Agricultural Sciences, 81(4): 324-9.

Laskar, M. A., Hynniewta, M. and Rao, C. S. 2009. In vitro propagation of Citrus indica Tanaka- An endangered progenitor species. Indian Journal of Biotechnology, 8: 311-316.

Li, S., Lin, Y. C., Ho, C. T. 2014. Formulated extract from multiple Citrus peels impairs dendritic cell functions and attenuates allergic contact hypersensitivity. International Immunopharmacol, 20: 12 - 23.

Liu, Y., Heying, E. and Tanumihardjo, S. 2012. History, global distribution, and nutritional importance of citrus fruits. Comprehensive reviews in food Science and Food Safety, 11 (6), 530545.

Lombardo, G., Alessandro, R., Scialabba, A., Sciandra, M. and De Pasquale, F. 2011. Direct organogenesis from cotyledons in cultivars of Citrus clementina Hort. Ex Tan. American Journal of Plant Science, 2: 237 - 244.

Momoko, I., Keiko, S. and Akira, I. 2013. Plant callus: Mechanisms of induction and repression. American Society of Plant Biology and the Plant Cell, 25 (9): 3159-3173.

Mukhtar, R., Khan, M. M., Rafiq. R., Shahid, A. and Khan, F. A. 2005. In-vitro regeneration and somatic embryogenesis in Citrus aurantifolia and Citrus sinensis. International Journal of agricultural Biology,7(3): $518-520$.

Normah, M. N., Hamidoh, S. and Ghani, F. D. 1997. Micropropagation of Citrus halimii- an endangered species of South-east Asia. Plant Cell, Tissue and
Organ Culture, 50: 225-227.

Nurul, H. Daud., Shashita, J. and Rozi, M. 2012. An improved surface sterilization technique for introducing leaf, nodal and seed explants of Aquilaria malaccensis from field sources into tissue culture. AsiaPacific Journal of Molecular Biology Biotechnology, 20 (2): 55-58.

Patil, V. K. 1987. High density planting and dwarfing rootstocks in citrus. A review. Journal of Maharashtra Agricultural University, 12:189-94.

Paudyal, K. P. and Haq, N. 2000. In vitro propagation of pummelo (Citrus grandis L. Osbeck). Journal of In Vitro Cell, Developmental Biology of Plants, 36: 511-516.

Pe'rez-Tornero, O. and Porras, I. 2008. Assessment of polyembryony in lemon: rescue and in vitro culture of immature embryos. Plant Cell Tissue Organ Culture, 93(2): 173-180.

Pospisilova J., Ticha I., Kadlecek P., Haised. L and Plzakova S. 1999. Acclimatization of micropropagated plants to ex vitro conditions. Journal of Biologia Plantarum, 42 (4): 481-497.

Raja, W. H. 2012. Studies on micropropagation in citrus rootstocks and effects of arbuscular mycorrhizal inoculation on in vitro raised plants. Ph.D. thesis, Indian Agricultural Research Institute, New Delhi, India.

Rakesh, K., Saurabh, V. and Nawaz, K. 2013. Comparative nutritional analysis and antioxidant activity of fruit juices of some Citrus spp. Octa Journal of Bioscience, 1 (1): 44-53.

Randhawa, G. S. and Srivastava, K. C. 1986. Citriculture in India. pp. 8-13. Hindustan Publishing Corporation, India.

Rangacharlu, V. S., Naidu, N., Anjaneyulu and Narsimharao, T. L. 1958. Performance of Sathgudi orange 
(C.sinensis Osbeck) on different rootstocks at Kodur (South India). Indian Journal of Horticulture, 15: 3558.

Rani, G., Singh, B., Sharma, S., Rehan, L., Zaidi, A. A., Nagpal, A. and Virk, G. S. 2004. Micropropagation of Kinnow (Citrus nobilis x Citrus deliciosa) through nodal segments. Journal of Indian Botanical Society, 83: 26-29.

Saini, H. K., Gill, M. S. and Gill, M. I. S. 2010. Direct shoot organogenesis and plant regeneration in rough lemon (Citrus jambhiri Lush.). Indian Journal of Biotechnology, 9(4): 419423.

Sarker, I., Islam, J., Shaekh, M. P. E., Rahman, M. M., Khan, H., Chowdhury, A. S. M. H. K., Mukim, M. S. I., Islam, R. and Haque, R. 2015. Establishment of a Standard Protocol for In Vitro Meristem Culture and Plant Regeneration of Citrus aurantifolia. Journal of Pharmacy and Biological Sciences, 10(2): 61-69.

Sarma, C., Borthakur, A., Singh, S., Mod, M. K. and Sen, P. 2011. Efficient in vitro plant regeneration from cotyledonary explants of Citrus reticulata L. Blanco. Annals of Biological Research, 2(6): $341-348$.

Saunt, J. 1990. Citrus varieties of the world, pp. 126. Sinclair International Ltd.

Savita, Singh, B., Virk, G. S. and Nagpal, A. (2011b). Efficient micropropagation protocol for regeneration of Citrus jambhiri Lush. using cotyledon as explant. Physiology and Molecular Biology of Plants, 17: 161-169.

Savita, Vijay, Virk, G. S. and Nagpal, A. 2010. Effect of explant types and plant growth regulators on callus induction and plantlet regeneration in Citrus jambhiri Lush. Environment and WeAn International Journal of Science and Technology, 5: 97-106.
Savita, Virk, G. S. and Nagpal, A. (2011a). In vitro selection of calli of Citrus jambhiri Lush. for tolerance to culture filtrate of Phytophthora parasitica and their regeneration. Physiology and Molecular Biology of Plants, 17: 4147.

Scora, R. W. 1975. On the history and origin of citrus. Bulletin of Torrey Botanical Club, 102: 369-375.

Sharma, S., Prakash, A. and Tele, A. 2009. In vitro propagation of Citrus rootstocks. Notulae Botanicae Horti Agrobotanici Cluj Napoca, 37: 84-88.

Shen, D-X., Wang, Y-Y. and Chen, L. G. 1998. Citrus genetics and breeding. pp 173. China Scientific Press, Beijing.

Shen, W., Xu, Y. and Lu, Y. H. 2012. Inhibitory effects of citrus flavonoids on starch digestion and antihyperglycemic effects in $\mathrm{Hep}_{2}$ cells. Journal of Agricultural Food Chemistry, 60 (38): 9609-9619.

Silva, R. P., Da Souza, E., Dos, S., Reboucos. F. S. and Almeida, W. A. B. 2005. Optimization of protocols for the invitro regeneration of plants of mandarin (Citrus reshmi Hort. Ex Tan.) cv. Cleoptara. Revista Brasileria de fruticultura., 27: 484-487.

Singh, I. P., Parthasarthy, V. A. and Handique, P. J. 2003. Effect of bioregulators on In-vitro raised microshoots of economically important Citrus species of the NEH region. Indian $J$ Horticulture., 60 :16-21.

Singh, L. B. 1962. Studies on the rootstocks for sweet orange in the web tropics I. Variety Rangtra. Hort. Adv, 6: 19-27

Singh, R., Sindhu, A., Singal, H. R. and Singh, R. 2004. Biochemical basis of resistance in chickpea (Cicer arietinum L.) against Fusarium wilt. Acta Phytopathologica et Entomologica Hungarica, 38: 13-19.

Singh, S. and Naqvi, S. A. M. H. 2001. Citrus, 
pp. 588. International Book Distributing Company, Lucknow, India.

Singh, S. and Rajam. M. V. 2010. Highly efficient and rapid plant regeneration in Citrus sinensis. Journal of Plant Biochemistry and Biotechnology, 19: 195-202.

Srivastava, R.K., Sandhu, A.S. and Sood, N (2001). In-vitro plant regeneration of Citrus aurantifolia through callus culture. J. Appl. Hort., 2(1): 28 - 30.

Talon, M. and Gmitter Jr, G. F. 2008. Citrus Genomics. International Journal of Plant Genomics, 2008: 1-17.

Taye, M. G., Debesay, B., Tesfahun, Y. and Brhanu, A. 2018. Optimization of an in vitro regeneration protocol for rough lemon rootstock (Citrus jambhiri L.) via direct organogenesis. Advances in Crop Science and Technology, 6 (1): 329.

Tusa, N. Grosser, J. W. and Gmitter, F. G. 1990. Plant regeneration of Valencia
Sweet orange, Femminello lemon and the interspecific somatic hybrid following protoplasm fusion. Journal of the American Society for Horticultural Science, 115 (6): 1043 1046.

Upadhyay, S., Syamal, M. M. and Itoo, H. 2010. Micropropagation of Sweet orange $c v$. Mosambi through shoot tips and nodal segments. Indian Journal of Horticulture, 67: 21-25.

Wang, S., Huang, Z., Yu, R., Zou, W. and Song, F. S. 2002. Studies on the induction of embryogenic callus, establishment of cell suspensions and plant regeneration in Citrus retuculata var. tanaka Hayata. J. South China Agricultural University, $23: 52-55$.

Yi, H-L. and Deng, X-X. 1998. Preliminary study on preservation of citrus calli. Journal of Huazhong Agricultural University, 17: 89-92.

\section{How to cite this article:}

Mudasir Iqbal, V. K. Wali, Parshant Bakshi, Kiran Kour, Vijay K. Razdan, B. K. Sinha and Sood, K. K. 2019. In vitro Propagation of Citrus Species through Callus Induction and Regeneration: A Review. Int.J.Curr.Microbiol.App.Sci. 8(10): 2282-2295. doi: https://doi.org/10.20546/ijcmas.2019.810.265 